\title{
Evaluasi Penggunaan Antibiotik Profilaksis pada Operasi Sesar di Rumah Sakit Swasta Purwokerto
}

\author{
Evaluation of Prophylactic Antibiotic Use for Cesarean Section \\ In a Purwokerto Private Hospital
}

\author{
Much Ilham Novalisa Aji Wibowo*, Tyas Dwi Utamiasih, Dina Ratna Juwita \\ Fakultas Farmasi, Universitas Muhammadiyah Purwokerto, Jl. Raya Dukuhwaluh, \\ Dukuhwaluh, Kembaran, Purwokerto 53182, Indonesia \\ *Corresponding author email: aji.wibowo.ump@gmail.com
}

Received 1-10-2019 Accepted 11-12-2019 Available online 30-12-2019

\begin{abstract}
ABSTRAK
Kondisi pembedahan sesar memungkinkan terjadinya infeksi pada lokasi pembedahan, tetapi secara umum terjadi peningkatan jumlah tindakan bedah sesar bahkan menjadi tren di Indonesia. Dampak negatif dari tindakan ini adalah adanya resiko infeksi setelah tindakan bedah sesar yaitu infeksi luka operasi. Berbagai studi telah menemukan penggunaan antibiotik pada pasien bedah sering kali tidak sesuai dengan standarnya. Penelitian ini bertujuan untuk mengevaluasi penggunaan antibiotik profilaksis yang digunakan pada pasien bedah sesar dan mengobservasi outcome terapi antibiotik profilaksis pada pasien bedah sesar. Penelitian ini menggunakan rancangan deskriptif observasional menggunakan data retrospektif berupa rekam medik pasien bedah sesar periode Agustus 2016 - Agustus 2018. Data diolah secara deskriptif nonanalitik meliputi jenis antibiotik yang digunakan, dosis yang digunakan, rute pemberian, dan waktu pemberian. Hasil penelitian dibandingkan dengan pedoman penggunaan antibiotik, Caesarean Section and Prophylactic Antibiotics 2014, Farmakologi dan Terapi Edisi VI, Pharmacotherapy Handbook $9^{\text {th }}$ Edition, Formularium RS " $\mathrm{X}$ " yang kemudian dikuantifikasi kesesuaiannya menggunakan rumus \% kesesuaian. Penelitian ini juga mendeskripsikan outcome terapi antibiotik profilaksis pada pasien. Hasil penelitian menemukan mayoritas pasien pada rentang umur ideal untuk mengalami masa kehamilan $(88,36 \%)$, lama hari perawatan rata-rata 4 hari $(48 \%)$ dengan kategori luka jahit bersih dan kering $(96,12 \%)$, serta $100 \%$ status keluar rumah sakit dalam keadaan membaik. Terdapat 29 jenis diagnosis pada pasien dan tertinggi pada kasus bedah sesar adalah diagnosis ketuban pecah dini. Terdapat kesesuaian penggunaan antibiotik profilaksis pada literatur PPAPC 2016 tetapi tidak sesuai 3 literatur lain yang menyebutkan obat cefazolin. Penggunan dosis dan waktu pemberian $A B$ pada RS $X$ berdasarkan pedoman terbaru pada PPAPC 2016. Walaupun tidak sepenuhnya mengikuti pedoman pengobatan tetapi mayoritas outcome terapi menunjukkan hasil yang baik berdasarkan nilai leukosit dan suhu tubuh pasien. Dapat disimpulkan terdapat ketidaksesuaian dengan pedoman yang digunakan pada penelitian ini, tetapi aspek rute
\end{abstract}


pemberian memiliki kesesuaian $100 \%$ berdasarkan semua pedoman atau literatur yang digunakan dalam penelitian ini. Outcome terapi yang diperoleh menghasilkan outcome yang baik berdasarkan nilai leukosit dan suhu tubuh pasien. Disarankan penelitian selanjutnya dilengkapi wawancara terstruktur dengan para dokter dan apoteker untuk memperoleh data komprehensif terkait penelitian penggunaan obat.

Kata kunci: antibiotik, bedah sesar, evaluasi penggunaan obat, profilaksis.

\begin{abstract}
In general, there is an increase in the number of cesarean sections in Indonesia. The Surgical Injury Infection is one of the risks of a cesarean section that should be considered accordingly. Numerous studies have shown the use of antibiotics in surgical patients is often not in accordance with the standards. This study aims to evaluate the use of prophylactic antibiotics used and observe the outcome of prophylactic antibiotic therapy in cesarean section patients. This study used an observational descriptive design with retrospective data collection in the form of medical records of cesarean patients in the period August 2016 - August 2018. Data were descriptive-non-analytically analyzed, including the type of antibiotics used, the dosage used, route of administration, and time of administration. The results of the study were compared to the guidelines for the use of antibiotics 2011, Caesarean Section and Prophylactic Antibiotics 2014, Pharmacology and Therapeutic Edition VI, Pharmacotherapy Handbook 9th Edition, and RS " $X$ " Formulary, which its suitability was subsequently quantified using the \% compliance formula. This study also described the outcome of prophylactic antibiotic therapy in patients. The results found that the majority of patients were in the ideal age range to experience pregnancy (88.36\%), the average length of treatment was 4 days (48\%), with clean and dry sewing wound categories (96.12\%) and the status of hospital discharge was in a state of improvement (100\%). There were 29 types of diagnoses in patients and the highest cases of cesarean section were the premature rupture of membranes. There was a suitable use of antibiotic prophylaxis in the 2016 PPAPC literature but it did not match 3 other references mentioning Cefazolin. The dose and time of administration of antibiotics in X Hospital followed the latest guidelines in PPAPC 2016. Although it does not fully follow the treatment guidelines, the majority of therapeutic outcomes showed good results, based on leukocyte values and body temperature of the patients. It can be concluded that there was a discrepancy with the guidelines used in this study, but an aspect of the route of administration had 100\% conformity based on all the guidelines or literature used in this study. The therapeutic outcomes were good, based on the values of leukocytes and the patient's body temperature. It is recommended that further research should be conducted, with structured interviews with doctors and pharmacists to obtain comprehensive data related to drug use.
\end{abstract}

Key words: antibiotic, evaluation of drug use, sectio caesarea, prophylaxis. 


\section{Pendahuluan}

Pembedahan merupakan tindakan penanganan penyakit atau kelainan tertentu yang bersifat invasif sehingga dapat menyebabkan luka di daerah pembedahan (Collin, 2005). Secara umum terjadi peningkatan jumlah tindakan bedah sesar bahkan menjadi tren di Indonesia (Pratiwi, 2015). Peningkatan juga terjadi di negara Brazil, terutama di rumah sakit swasta sebesar $86,2 \%$ dari total persalinan (Vieira et al., 2015). Dampak negatif dari tindakan ini adalah adanya resiko infeksi setelah tindakan bedah yaitu Infeksi Luka Operasi/ILO (Haridas dan Malangoni, 2008). Hal ini diperkuat oleh penelitian serupa, yang menyatakan kejadian ILO sebesar $6,4 \%$ pada pasien bedah sesar (Oktaviani et al., 2015). Hasil survey pravalensi 11 rumah sakit di Jakarta tahun 2003 juga didapati angka ILO 19,9\% (Litbangkes, 2018).

Pemberian antibiotik profilaksis digunakan untuk mencegah terjadinya resiko ILO pada pasien yang belum terkena infeksi namun berpeluang besar terhadap resiko infeksi (Liu et al., 2016). Menurut Bratzler et al. (2013) sekitar 30$50 \%$ penggunaan antibiotik di rumah sakit digunakan sebagai profilaksis bedah. Tingginya penggunaan tersebut memerlukan perhatian khusus pada penggunaan antibiotik profilaksis.

Menurut Wibowo et al. (2018) ditemukan sejumlah potensi interaksi yang dapat terjadi pada pemberian Antibiotik. Hasil penelitian Nurkusuma dan Dewi (2017) dan Prasetya (2013) menyebutkan kesesuaian penggunaan antibiotik profilaksis dapat menurunkan angka infeksi operasi dan menurunkan resiko ILO (Prasetya, 2013).

Penggunaan antibiotik profilaksis pada pasien bedah yang tidak sesuai dapat menyebabkan dampak jangka panjang yaitu resiko resistensi (Bratzler et al., 2013). Berbagai studi telah menemukan penggunaan antibiotik pada pasien bedah sering kali tidak sesuai dengan standarnya (Hing et al., 2005; Hadi et al., 2008). Bahkan diperlukan peningkatan kepatuhan terhadap pedoman antibiotik profilaksis bedah (Gouvêa et al., 2015).

Penelitian ini bertujuan untuk mengevaluasi penggunaan antibiotik profilaksis yang digunakan pada pasien bedah sesar di salah satu rumah sakit di Purwokerto yang memiliki kasus bedah sesar tertinggi. Penelitian ini juga mengobservasi outcome terapi antibiotik profilaksis pada pasien bedah sesar.

\section{Metode Penelitian}

Penelitian ini menggunakan rancangan deskriptif observasional menggunakan data retrospektif rekam medik pasien bedah sesar periode Agustus 2016 - Agustus 2018 di salah satu rumah sakit swasta di Purwokerto (Rumah Sakit " $X$ "). Penentuan populasi sampel berdasarkan rumus slovin (Ryan, 2013), dari 423 populasi target didapat 232 populasi sampel selama periode tersebut. Teknik sampling sistematis digunakan pada penelitian ini agar dapat mewakili semua data populasi. Peneliti mengambil sampel pertama secara acak sedangkan sampel selanjutnya dipilih 
secara sistematis menurut pola tertentu (Triyono, 2003).

Data diolah secara deskriptif nonanalitik berdasarkan indikator yang direkomendasikan oleh World Health Organization (WHO) (Holloway dan Green, 2003) meliputi jenis antibiotik yang digunakan, dosis yang digunakan, rute pemberian, dan waktu pemberian. Hasil penelitian dibandingkan dengan pedoman penggunaan antibiotik/PPAB 2011, Caesarea Section and Prophylactic Antibiotics (CSPA) 2014 (Shamna et al., 2014), Farmakologi dan Terapi Edisi VI (Ganiswara, 2017), Pharmacotherapy Handbook (Wells et al., 2015), Formularium RS " $X$ " yang kemudian dikuantifikasi kesesuaiannya menggunakan rumus \% kesesuaian. Penggunaan beberapa referensi guideline dengan tahun berbeda agar dapat memperluas pembahasan dalam penelitian ini. Outcome terapi dinilai berdasarkan nilai leukosit dengan parameter normal $3600-11.000 / \mu l$ dan suhu tubuh dengan parameter normal 36-37 ㅇ. A Analisis statistik deskriptif digunakan untuk mengukur frekuensi, rerata, median, modus, dan persentil dari setiap variabel menggunakan software Microsoft Excel 2016. Penelitian ini telah mendapatkan status telaah exemted (dapat dilakukan) dari Komisi Etik Penelitian Kesehatan Fakultas Kedokteran Universitas Jendral Soedirman dengan nomor reg 324/KEPK/XII/2018.

\section{Hasil dan Pembahasan}

Karakteristik Pasien Bedah Sesar di Rumah Sakit "X" Purwokerto

$$
\text { Penelitian telah dilakukan }
$$

terhadap 232 data rekam medik pasien bedah sesar di salah satu rumah sakit swasta di Purwokerto periode Agustus 2016 - Agustus 2018. Data demografi pasien dapat dilihat pada Tabel 1.

Mayoritas pasien berusia 20-35 tahun yang merupakan rentang usia yang ideal bagi seorang wanita untuk mengalami proses kehamilan dan kelahiran (Indiarti, 2015) hal ini juga dikemukakan oleh penelitian lain yang juga menemukan hal serupa (Karminingtyas et al., 2018). Pada rentang umur tersebut organ reproduksi wanita telah sempurna, sedangkan untuk usia kurang dari 20 tahun dikhawatirkan dapat menyebabkan persalinan berjalan dengan lama dan terhenti karena otot peritonial dan perineum belum bekerja dengan baik. Sedangkan wanita yang berusia lebih dari 35 tahun dianggap beresiko besar terhadap ibu dan janin (Prawirohardjo, 2010; Sumanti et al., 2016). Diperoleh presentase Lenght of Stay (LOS) perawatan selama 4 hari, range tersebut menunjukkan bahwa lama perawatan pasien bedah sesar telah memenuhi parameter yang ditetapkan pada standar lama rawat Average Lenght of Stay (AvLOS) maksimal 6-9 hari (Kemenkes RI, 2011). Menurut Prasetya (2013) dan Mutmainah et al. (2014), lama rawat pasien di rumah sakit dapat diasumsikan bahwa pasien menerima pengobatan yang sesuai dengan indikasinya, sehingga 
menghasilkan efektifitas terapi yang optimal. Data ini berkaitan dengan kondisi luka jahit pasien mayoritas pada kategori bersih dan kering (Tabel 1). Lamanya hari rawat inap dikarenakan kondisi infeksi nosokomial maupun penyembuhan luka operasi serta kondisi nonmedis pasien dan faktor penyembuhan luka dapat berpengaruh pada lama rawat pasien bedah dengan penggunaan antibiotik profilaksis yang sesuai (Elly dan Asmawati, 2016). Secara umum pasien sesar pada penelitian ini memiliki efisiensi lama rawat inap yang baik karena nilai LOS tidak melampaui nilai maksimal AvLOS. Pasien keluar dari rumah sakit dalam kondisi membaik ditandai dengan sebagian besar pasien sesar memiliki keadaan luka pembedahan bersih dan kering.

Tabel 1. Karakteristik pasien yang menjalani bedah sesar

\begin{tabular}{lcc}
\hline Karakteristik & Jumlah Pasien & Persentase (\%) \\
\hline Umur & 3 & \\
$\quad<20$ tahun & 205 & 1,29 \\
$20-35$ & 18 & 88,36 \\
$>35$ tahun & & 7,75 \\
Lama Perawatan & 70 & \\
3 hari & 113 & 30,17 \\
4 hari & 33 & 48,7 \\
5 hari & 16 & 14,22 \\
$>5$ hari & 223 & 6,89 \\
Luka Jahit & 9 & 96,12 \\
Bersih \& kering & & 3,87 \\
Bersih \& lochea & 0 & \\
banyak & 232 & 0 \\
Status Keluar & 0 & 100 \\
Sembuh & & 0 \\
Membaik & & \\
Meninggal & &
\end{tabular}

Sumber: data primer, 2019.

Identifikasi Diagnosis Pasien Bedah Sesar di Rumah Sakit " $X$ " Purwokerto

Wanita dengan persalinan keadaan gawat mengharuskan ibu untuk melahirkan bayi melalui prosedur bedah sesar ketika terdeteksi indikasi medis (Sumanti et al., 2016). Selain itu tindakan bedah sesar dapat dilakukan walaupun tidak terdapat indikasi medis atau diagnosis medis yang beresiko seperti tindakan persalinan bedah sesar atas permintaan pasien (Ayuningtyas et al., 2018). Indikasi yang dialami ibu hamil yang melakukan tindakan bedah sesar dapat dilihat pada Tabel 2.

Terdapat beragam diagnosa pada pasien bedah sesar, diagnosis tertinggi pada keadaan pasien Ketuban Pecah Dini (KPD). Wanita hamil yang terdiagnosis KPD maka tindakan 
persalinan yang dilakukan yaitu dengan persalinan sesar (Prawirohardjo, 2010). Keadaan ini terjadi pada usia kehamilan di bawah 37 minggu atau pada akhir kehamilan yang menyebabkan peningkatan resiko infeksi pada janin dan ibu. WHO (2015) melaporkan insiden KPD terjadi pada kehamilan sebanyak $70 \%$. Hasil serupa juga ditemukan oleh Mutmainah et al. (2014) yang menunjukkan indikasi pasien bedah sesar terbanyak pada insiden KPD. Tindakan bedah sesar setelah ada indikasi KPD bertujuan untuk menghindarkan infeksi pada janin maupun ibu dan dikhawatirkan belum siap untuk merasakan rasa sakit pada saat persalinan secara normal.

Tabel 2. Identifikasi diagnosis pasien bedah sesar

\begin{tabular}{llcc}
\hline No. & Diagnosis & Jumlah & Persentase (\%) \\
\hline 1 & Ketuban Pecah Dini (KPD) & 43 & 18,5 \\
2 & Riwayat SC & 39 & 16,8 \\
3 & Gagal Induksi & 28 & 12,1 \\
4 & Serotinus & 27 & 11,6 \\
5 & Sungsang & 21 & 9,1 \\
6 & Oligohidramnion & 15 & 6,5 \\
7 & Plasenta Previa & 7 & 3,0 \\
8 & Gameli & 6 & 2,6 \\
9 & Presentasi Kaki & 6 & 2,6 \\
10 & Kala 1 dan 2 lama & 5 & 2,2 \\
11 & Fetal Distress & 4 & 1,7 \\
12 & Bokong & 3 & 1,3 \\
13 & Kala Lama & 3 & 1,3 \\
14 & Miopi Berat & 2 & 0,9 \\
15 & Atas Permintaan Sendiri & 2 & 0,9 \\
16 & Letak Oblig & 2 & 0,9 \\
17 & Varises Vagina & 2 & 0,9 \\
18 & Riwayat Asma & 2 & 0,9 \\
19 & Partus Prematur & 2 & 0,9 \\
20 & Gagal VBAS & 2 & 0,9 \\
21 & Hidrocefalus & 2 & 0,9 \\
22 & Hemeroid & 2 & 0,9 \\
23 & Inpartus & 1 & 0,4 \\
24 & Low Back Pain (LBP) & 1 & 0,4 \\
25 & Pendarahan & 1 & 0,4 \\
26 & Lilitan Tali Pusat & 1 & 0,4 \\
27 & Preeklamsi Berat & 1 & 0,4 \\
28 & PPI & 1 & 0,4 \\
29 & Condiloma & & \\
& & 1 & 0,0 \\
\hline
\end{tabular}

Sumber: data primer, 2019. 
Evaluasi Kesesuaian Penggunaan Antibiotik Profilaksis

Jenis antibiotik yang digunakan sebagai antibiotik profilaksis dan kesesuaiannya terhadap beberapa pedoman dapat dilihat pada Tabel 3 . Bedah sesar merupakan salah satu tindakan operasi bebas kontaminasi sehingga sangat direkomendasikan penggunaan antibiotik profilaksis. Pemberian antibiotik profilaksis bedah terbukti efektif dalam mencegah infeksi luka operasi (Cheng et al., 2007). Hasil analisis pada Tabel 3 didapatkan hasil penggunaan antbiotik profilaksis $100 \%$ sesuai dengan formularium dan PPAPC 2016 yaitu menggunakan antibiotik ceftriaxone. Ceftriaxone merupakan antibiotik golongan sefalosporin golongan 3 yang memiliki spektrum aktifitas yang luas. Pertimbangan penggunaan profilaksis ceftriaxone yang memiliki spektrum aktifitas pada gram positif maupun negatif sehingga dapat menghambat bakteri ketika dilakukan pembedahan (Ganiswara, 2017).

$$
\text { Pedoman PPAB } 2011
$$

merekomendasikan antibiotik golongan sefalosporin golongan 1 dan 2, sedangkan antibiotik yang digunakan pada pasien bedah sesar yang tercatat pada rekam medik pasien yaitu ceftriaxone yang merupakan antibiotik golongan sefalosporin generasi 3 . Ketidaksesuaian dengan pedoman yang lain yaitu pada CSPA 2014, PHD Edisi 9 dan Farmakologi dan Terapi edisi 6 yang ketiganya merekomendasikan penggunaan antibiotik profilaksis antibiotik cefazolin. Berdasarkan formularium RS " $X$ " penggunaan ceftriaxone digunakan sebagai profilaksis bedah sesar. Menurut Geroulanos et al. (2001) salah satu alasan ceftriaxone digunakan pada operasi sesar adalah waktu paruh yang relatif lama (8 jam). Karenanya, area di bawah kurva sangat panjang dan hanya menggunakan 1 dosis untuk prosedur operasi yang panjang. Tindakan operasi sesar bisa memakan waktu lama disesuaikan dengan diagnosis yang ditegakkan.

Beberapa negara termasuk FDA membatasi penggunaan ceftriaxone karena lebih mahal daripada cefazolin, tetapi ceftriaxone telah diterima oleh komunitas medis di berbagai negara sebagai obat yang umum digunakan untuk profilaksis (Geroulanos et al., 2001). Berdasarkan informasi ini RS " $X$ " masih mempertahankan ceftriaxone sebagai antibiotik profilaksis pada kasus bedah sesar.

Evaluasi Kesesuaian Penggunaan Dosis Antibiotik Profilaksis

Terdapat ketidaksesuaian dengan pedoman yang direkomendasikan oleh PPAB 2011 dan CSPA 2014 pada penggunaan antibiotik profilaksis ceftriaxone 1 gram dan 2 gram (Tabel 4). Dosis antibiotik profilaksis tidak boleh terlampau kecil karena dapat menyebabkan efek terapi di bawah kadar hambat minimal sehingga tidak menghasilkan efek terapi yang diinginkan (Ganiswara, 2017). Pemberian dosis pada penggunaan antibiotik profilaksis harus disesuaikan dengan indikasi yang ditemukan. Dampak lain dari terjadinya infeksi pada 
luka operasi sesar karena penggunaan dosis yang tidak sesuai sehingga efektifitas untuk menghambat kuman penyebab infeksi tidak maksimal. Menurut Alekwe et al. (2008), ceftriaxone lebih mudah diberikan dan dianjurkan pemberian dosis tunggal untuk profilaksis pada pasien bedah sesar tanpa faktor risiko tambahan infeksi. Pada penelitian ini ditemukan dosis ceftriaxone $1 \mathrm{~g}$ lebih banyak digunakan daripada 2 g. Penggunaan dosis lebih tinggi dimungkinkan karena pasien memiliki faktor resiko lain yang menyebabkan resiko infeksi lebih tinggi (Alekwe et al., 2008). Menurut Kemenkes RI (2011) jika pelaksanaan pembedahan 3 jam atau kurang, cukup diberikan dosis tunggal, tetapi jika pembedahan lebih dari 3 jam, maka memerlukan dosis efektif tambahan.

Tabel 3. Kesesuaian jenis antibiotik profilaksis

\begin{tabular}{|c|c|c|c|c|c|c|}
\hline \multirow[t]{2}{*}{ Pedoman } & \multicolumn{2}{|c|}{ Jenis Antibiotik Profilaksis } & \multicolumn{2}{|c|}{ Jumlah } & \multicolumn{2}{|c|}{ Persentase (\%) } \\
\hline & Pedoman & RSU "X" & SP & TSP & SP & TSP \\
\hline PPAB 2011 & $\begin{array}{l}\text { Sefalosporin Generasi } 1 \\
\text { dan } 2\end{array}$ & Ceftriaxone & - & 232 & - & 100 \\
\hline CSPA 2014 & Cefazolin & Ceftriaxone & - & 232 & - & 100 \\
\hline PHD Edisi 9 & Cefazolin & Ceftriaxone & - & 232 & - & 100 \\
\hline $\begin{array}{l}\text { Farmakologi } \\
\text { dan Terapi VI } \\
\text { Tahun } 2016\end{array}$ & Cefazolin & Ceftriaxone & - & 232 & - & 100 \\
\hline $\begin{array}{l}\text { Formularium } \\
\text { RSU “ } X \text { " }\end{array}$ & Ceftriaxone & Ceftriaxone & 232 & - & $100 \%$ & - \\
\hline PPAPC 2016 & $\begin{array}{l}\text { Ceftriaxone dan } \\
\text { Ceftriaxone+Gentamisin }\end{array}$ & Ceftriaxone & 232 & - & $100 \%$ & - \\
\hline
\end{tabular}

Sumber: Data primer, 2016-2018. Keterangan: $S P=$ sesuai pedoman; $T S P=$ tidak sesuai pedoman; $\mathrm{PPAB}=$ Pedoman Penggunaan Antibiotik 2011; CSPA=Caesarea Section and Prophylactic Antibiotics 2014; PHD=Pharmacology Handbook Dipiro Edisi 9 2015; PPAPC=Pola Penggunaan Antibiotik Profilaksis pada Sesar 2016.

Tabel 4. Kesesuaian dosis antibiotik profilaksis

\begin{tabular}{|c|c|c|c|c|c|c|}
\hline \multirow[t]{2}{*}{ Pedoman } & \multicolumn{2}{|c|}{ Dosis Antibiotik Profilaksis } & \multicolumn{2}{|c|}{ Jumlah } & \multicolumn{2}{|c|}{ Presentase } \\
\hline & Pedoman & RSU “ $X$ " & SP & TSP & SP & TSP \\
\hline \multirow[t]{2}{*}{ CSPA 2014} & Cefazolin 2 gram & Ceftriaxone $1 \mathrm{~g}$ & - & & - & \\
\hline & & Ceftriaxone $2 \mathrm{~g}$ & - & 232 & - & $100 \%$ \\
\hline \multirow[t]{2}{*}{ PHD Edisi 9} & Cefazolin 2 gram & Ceftriaxone $1 \mathrm{~g}$ & - & 232 & - & 1000 \\
\hline & & Ceftriaxone $2 \mathrm{~g}$ & - & 232 & - & $100 \%$ \\
\hline Formularium & Ceftriaxone 1 gram & Ceftriaxone $1 \mathrm{~g}$ & 183 & - & $78,8 \%$ & - \\
\hline RSU “ $X$ ” & dan 2 gram & Ceftriaxone $2 \mathrm{~g}$ & 49 & - & $21,1 \%$ & - \\
\hline \multirow[t]{2}{*}{ PPAPC 2016} & Ceftriaxone 1 gram & Ceftriaxone $1 \mathrm{~g}$ & 232 & - & $100 \%$ & - \\
\hline & & Ceftriaxone $2 \mathrm{~g}$ & - & 49 & 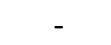 & $21,1 \%$ \\
\hline
\end{tabular}



Evaluasi Kesesuaian Rute Pemberian
Antibiotik Profilaksis

Semua rute pemberian antibiotik pada penelitian ini sesuai dengan pedoman yang digunakan yaitu secara intravena. Pemberian secara intaravena memiliki beberapa keefektifan dimana obat secara cepat didistribusikan sehingga antibiotik akan segera mencapai jaringan dan memberikan efek terapi yang adekuat (Ganiswara, 2017). Menurut Rusdiana et al. (2016) dan Kemenkes RI (2011) rute pemberian intravena pada tatalaksana pembedahan sesar direkomendasikan karena pemberian intravena mampu mendistribusikan obat ke dalam jaringan lebih cepat serta telah terbukti efektif dapat mempertahankan kadar serum dan konsentrasinya dalam jaringan sehingga efektif pada infeksi luka operasi pada tindakan pembedahan.

Evaluasi Kesesuaian Waktu Pemberian Antibiotik Profilaksis

Waktu pemberian akan berkaitan dengan kadar obat yang diharapkan ketika pasien menjalani tindakan bedah sesar, data hasil kesesuaian waktu pemberian antibiotik dapat dilihat pada Tabel 5.

Tabel 5. Kesesuaian waktu pemberian antibiotik profilaksis

\begin{tabular}{|c|c|c|c|c|c|c|}
\hline \multirow[t]{2}{*}{ Pedoman } & \multicolumn{2}{|c|}{ Jenis Antibiotik Profilaksis } & \multicolumn{2}{|c|}{ Jumlah } & \multicolumn{2}{|c|}{ Persentase (\%) } \\
\hline & Pedoman & RSU “X” & SP & TSP & SP & TSP \\
\hline PPAB 2011 & $\begin{array}{l}\text { Diberikan } \leq 30 \text { menit } \\
\text { sebelum insisi kulit atau } \\
\text { diberikan pada saat } \\
\text { anastesi }\end{array}$ & $\begin{array}{l}1 \text { jam sebelum } \\
\text { insisi }\end{array}$ & - & 232 & - & 100 \\
\hline CSPA 2014 & $\begin{array}{l}\text { Diberikan } 30 \text { menit } \\
\text { sebelum insisi kulit }\end{array}$ & $\begin{array}{l}1 \text { jam sebelum } \\
\text { insisi }\end{array}$ & - & 232 & - & 100 \\
\hline PHD Edisi 9 & $\begin{array}{l}\text { Sebelum insisi kulit atau } \\
\text { setelah penjepitan tali } \\
\text { pusat }\end{array}$ & $\begin{array}{l}1 \text { jam sebelum } \\
\text { insisi }\end{array}$ & - & 232 & - & 100 \\
\hline $\begin{array}{l}\text { Farmakologi } \\
\text { dan Terapi } 6\end{array}$ & Saat induksi anastesi & $\begin{array}{l}1 \text { jam sebelum } \\
\text { insisi }\end{array}$ & - & 232 & - & 100 \\
\hline $\begin{array}{l}\text { Formularium } \\
\text { RSU " } X \text { " }\end{array}$ & 1 jam sebelum insisi & $\begin{array}{l}1 \text { jam sebelum } \\
\text { insisi }\end{array}$ & 232 & - & $100 \%$ & - \\
\hline PPAPC 2016 & $\begin{array}{l}0-2 \text { jam sebelum } \\
\text { operasi }\end{array}$ & $\begin{array}{l}1 \text { jam sebelum } \\
\text { insisi }\end{array}$ & 232 & - & $100 \%$ & - \\
\hline
\end{tabular}

Sumber: data primer, 2019. Keterangan: $S P=$ sesuai pedoman; TSP=tidak sesuai pedoman; PPAB=Pedoman Penggunaan Antibiotik 2011; CSPA=Caesarea Section and Prophylactic; Antibiotics 2014; PHD= Pharmacology Handbook Dipiro Edisi 9 2015; PPAPC=Pola Penggunaan Antibiotik Profilaksis pada Sesar 2016.

Hasil penelitian menunjukkan waktu pemberian antibiotik profilaksis mengikuti panduan formularium dan PPAPC 2016. Pedoman PPAB 2011 dan 
CSPA 2014 merekomendasikan waktu pemberian kurang dari atau sama dengan 30 menit sebelum insisi. Hal ini dilakukan untuk untuk menghindari penekanan flora normal pada janin dan diharapkan ketika pembedahan kadar antibiotik telah mencapai kadar maksimal sehingga mampu memberikan efek terapi yang baik (Shamna et al., 2014). Berbeda dengan pedoman PHD Edisi 9 tahun 2015 yang direkomendasikan menurut PHD Edisi 9 yaitu sebelum insisi atau setelah penjepitan tali pusat. Hal ini bertujuan agar janin tidak terpapar efek samping dari obat yang diberikan yang dimungkinkan dapat menembus membran plasenta bayi. Penelitian (Grujić et al., 2010) menyatakan ceftriaxone dan cefazolin mampu menembus sawar plasenta bayi sehingga waktu pemberian dilakukan setelah penjepitan tali pusat untuk meminimalisir efek samping obat pada bayi. Hasil penelitian menunjukkan dominasi pada kategori tidak sesuai dengan pedoman dengan rentang perbedaan waktu 30 menit. Antibiotik profilaksis diberikan dalam dosis yang menunjukkan konsentrasi efektif sebelum kontaminasi bakteri intraoperatif. Pemberian yang dianjurkan adalah 30-45 menit sebelum insisi kulit (biasanya bersamaan dengan induksi anestesia) (Kemenkes RI, 2011). Outcome Terapi Penggunaan Antibiotik Profilaksis Pasien Sesar

Outcome terapi penggunaan antibiotik profilaksis dapat dilihat dari parameter klinis nilai leukosit dan suhu tubuh. Parameter tersebut erat kaitannya dengan gejala ketika pasien mengalami infeksi luka operasi. Data outcome terapi dapat dilihat pada Tabel 6.

Tabel 6. Outcome terapi penggunaan antibiotik profilaksis pasien sesar

\begin{tabular}{llcc}
\hline Kategori & \multicolumn{1}{c}{ Outcome } & $\begin{array}{c}\text { Jumlah } \\
\text { (n=232) }\end{array}$ & $\begin{array}{c}\text { Persentase } \\
\text { (\%) }\end{array}$ \\
\hline Nilai leukosit pasien bedah & Leukosit $<3600$ & 1 & 0,4 \\
sesar & Leukosit normal 3600-11000 & 172 & 74,1 \\
\multirow{2}{*}{ Nilai suhu tubuh pasien } & Leukosit $>11000$ & 59 & 25,4 \\
bedah sesar & Suhu tubuh $<36{ }^{\circ} \mathrm{C}$ & - & 0 \\
& Suhu tubuh $36-37^{\circ} \mathrm{C}$ & 219 & 94,4 \\
& Suhu tubuh $>37^{\circ} \mathrm{C}$ & 13 & 5,6 \\
\hline
\end{tabular}

Sumber: data primer, 2016-2018.

Tanda terjadinya infeksi dan peradangan pada luka dapat dilihat dengan mata untuk melihat keadaan suatu peradangan yang terjadi dan untuk menginterpretasikan secara pasti maka dapat dilihat pemerikasaan data klinik 
meliputi suhu tubuh dan leukosit yang mengalami peningkatan di atas nilai normal jika terdapat suatu inflamasi, pemilihan antibiotik yang sesuai dapat menghasilkan luaran kinis yang baik (Ganiswara, 2017; Karminingtyas et al., 2018). Tindakan bedah sesar termasuk kategori bedah clean contaminated sehingga terjadinya proses infeksi dapat merangsang tubuh bereaksi terhadap peradangan yang terjadi yang mengakibatkan proses pengeluaran leukosit pada tempat peradangan. Penyebab infeksi seperti bakteri maupun virus dapat menstimulasi respon imun tubuh sehingga pasien dapat mengalami peningkatan suhu tubuh atau febris sebagai tanda awal adanya infeksi (Ganiswara, 2017). Penjelasan tersebut diperkuat oleh penelitian Alsaywid dan Smith (2013) yang menyatakan penggunaan antibiotik profilaksis mampu mengurangi resiko terjadinya infeksi ditandai dengan penurunan tanda tanda infeksi secara bermakna seperti demam.

Berdasarkan hasil yang didapat dalam evaluasi penggunaan antibiotik profilaksis pada pasien bedah sesar di RSU " $X$ " di Purwokerto periode Agustus 2016-Agustus 2018 pada 232 sampel data rekam medik, didapatkan hasil karakteristik pasien bedah sesar sebagian besar berumur 20-35 tahun yang merupakan umur yang ideal karena alat reproduksi sudah sempurna serta aman jika dilakukan persalinan dengan pembedahan. Lama rawat inap berkisar 3-7 hari dengan status keluar membaik dan luka operasi bersih dan kering, hal tersebut menandakan pasien memiliki efisiensi lama rawat inap serta kualitas pengobatan yang diterima memiliki efisiensi dan kualitas yang baik. Wanita yang menjalani bedah sesar memiliki indikasi medis terbanyak pada kasus KPD, tujuan dipilih tindakan pembedahan untuk meminimalisir resiko berbahaya ketika dilakukan persalinan secara normal. Seluruh wanita yang menjalani bedah sesar mendapatkan terapi antibiotik profilaksis sebagai langkah pencegahan infeksi. Evaluasi penggunaan antibiotik profilaksis pada aspek kesesuaian jenis antibiotik, waktu pemberian, dan dosis yang digunakan, kesesuaian yang didapat sesuai dengan formularium rumah sakit dan PPAPC 2016 sedangkan untuk pedoman yang lain tidak sesuai. Aspek yang memiliki kesesuaian dengan semua pedoman yang digunakan dalam penelitian ini yaitu hanya pada aspek rute pemberian yaitu secara intravena $100 \%$. Walaupun terdapat ketidaksesuaian pada beberapa aspek dan pedoman, tetapi penggunaan antibiotik ceftriaxone 1 dan 2 gram secara intravena 1 jam sebelum insisi mendapatkan luaran terapi yang baik dengan outcome terapi leukosit dan suhu tubuh pada sebagian besar pasien sesar berkisar pada nilai normal.

\section{Simpulan}

Terdapat ketidaksesuaian dengan pedoman yang digunakan pada penelitian ini, tetapi aspek rute pemberian didapatkan hasil kesesuaian $100 \%$ berdasarkan semua pedoman atau literatur yang digunakan dalam 
penelitian ini. Outcome terapi yang diperoleh menghasilkan outcome yang baik berdasarkan nilai leukosit dan suhu tubuh pasien. Disarankan penelitian selanjutnya dilengkapi dengan wawancara terstruktur dengan para dokter dan apoteker untuk memperoleh data komprehensif terkait penelitian penggunaan obat.

\section{Daftar Pustaka}

Alekwe, L.O., Kuti, O., Orji, E.O., Ogunniyi., $\quad$ S.O. 2008. Comparison of ceftriaxone versus triple drug regimen in the prevention of cesarean section infectious morbidities. Journal of Maternal-Fetal and Neonatal Medicine, 21(9):638-642.

Alsaywid, B. dan Smith, G. 2013. Antibiotic prophylaxis for transurethral urological surgeries: systematic review. Urology Annals, 5(2):61-74.

Ayuningtyas, D., Oktarina, R., Misnaniarti, Sutrisnawati, N.N.D. 2018. Etika kesehatan pada persalinan melalui sectio caesarea tanpa indikasi medis. Media Kesehatan Masyarakat Indonesia, 14(1):9-16.

Wells, B.G., DiPiro, J.T., Schwinghammer, T.L., DiPiro, C.V. 2015. Pharmacotherapy Handbook. $9^{\text {th }}$ ed. New york: Mc Graw Hill Education.

Bratzler, D.W., Dellinger, E.P., Olsen, K.M., Perl, T.M., Auwaerter, P.G., Bolon, M.K., Fish, D.N., Napolitano, L.M., Sawyer, R.G., Slain, D., Steinberg, J.P.,
Weinstein, R.A. 2013. Clinical practice guidelines for antimicrobial prophylaxis in surgery. American Journal of Health-System Pharmacy: AJHP: Official Journal of the American Society of Health-System Pharmacists, 70(3):195-283.

Cheng, K., Li. J., Kong, Q., Wang, C., Ye, N., Xia, G. 2007. Risk factors for surgical site infection in a teaching hospital: a prospective study of 1,138 patients. Patient Preference and Adherence, 9:1171-1177.

Collin, P. 2005 Dictionary of Medical Terms. $4^{\text {th }}$ ed. London: A\&C Black Publishers Ltd.

Elly, N. dan Asmawati. 2016. Faktorfaktor yang mempengaruhi lama hari rawat pasien laparotomi di Rumah Sakit DR. M. Yunus Bengkulu. Jurnal IImu Kesehatan, 8:14-18.

Ganiswara, G. 2017. Farmakologi dan Terapi. Edisi VI. Jakarta: Departemen Farmakologi Fakultas Kedokteran Universitas Indonesia.

Geroulanos, S., Marathias, K., Kriaras, J., Kadas, B. 2001. Cephalosporins in surgical prophylaxis. Journal of Chemotherapy, 13(1):23-26.

Gouvêa, M., Novaes Cde, O., Pereira, D.M., Iglesias, A.C. 2015. Adherence to guidelines for surgical antibiotic prophylaxis: a review. Brazilian Journal of Infectious Diseases, 19(5):517524. 
Grujić, Z., Popović, J., Bogavac, M., Grujić, I. 2010. Preoperative administration of cephalosporins for elective caesarean delivery. Srpski Arhiv za Celokupno Lekarstvo, 138(9-10):600-603.

Hadi, U., Duerink, D.O., Lestari, E.S., Nagelkerke, N.J., Werter, S., Keuter, M., Suwandojo, E., Rahardjo, E., van den Broek, P., Gyssens, I.C. 2008. Survey of antibiotic use of individuals visiting public healthcare facilities in Indonesia. International Journal of Infectious Diseases, 12(6):622629.

Haridas, M. dan Malangoni, M.A. 2008 Predictive factors for surgical site infection in general surgery. Surgery, 144(4):496-503.

Hing, W.C. Yeoh, T.T., Yeoh, S.F., Lin, R.T., Li, S.C. 2005. An evaluation of antimicrobial prophylaxis in paediatric surgery and its financial implication. Journal of Clinical Pharmacy and Therapeutics, 30(4):371-381.

Holloway, K. dan Green, T. 2003 Drug and therapeutics committees. Geneva: Department of Essential Drugs and Medicines Policy.

Indiarti, M.T. 2015. Panduan Lengkap Kehamilan Persalinan dan Perawatan Bayi. Yogyakarta: Indoliterasi.

Karminingtyas, S.R., Oktianti, D., Furdiyanti, N.H. 2018. Keefektifan penggunaan antibiotik profilaksis pada pasien bedah sesar (sectio caesarea).
Cendekia Journal of Pharmacy, 2(1):22-31.

Kemenkes RI. 2011. Pedoman Umum Penggunaan Antibiotik Indonesia. Jakarta: Kemenkes RI.

Litbangkes. 2018. Hasil Utama Riset Kesehatan Dasar, Kementrian Kesehatan Republik Indonesia. Jakarta: Kemenkes RI.

Liu, R., Lin, L., Wang, D. 2016. Antimicrobial prophylaxis in caesarean section delivery. Experimental and Therapeutic Medicine, 12(2):961-964.

Mutmainah, N., Setyati, P., Handasari, N. 2014. Evaluation of the use and effectiveness of antibiotics for prophylactic in patients with cesarean section at hospitals in Surakarta in 2010. Indonesian Journal of Clinical Pharmacy, 3(2):44-49.

Nurkusuma, D.D. dan Dewi, A. 2017. Efisiensi penggunaan antibiotik profilaksis di Rumah Sakit Umum Daerah Temanggung. Proceeding Health Architecture, 1(1):67-73.

Oktaviani, F., Wahyono, D., Yuniarti, E. 2015. Evaluasi penggunaan antibiotik profilaksis terhadap kejadian infeksi luka operasi pada operasi sectio caesarea. Jurnal Manajemen dan Pelayanan Farmasi, 5(4):255258.

Prasetya, D.B. 2013. Efektifitas penggunaan antibiotik pada pasien seksio sesarea elektif di Rumah Sakit X Sidoarjo. Jurnal Ilmiah Mahasiswa, 2(2):1-10. 
Pratiwi, A.M. 2015. Fenomena operasi cesar sebagai tren. Jurnal Perempuan.

https://www.jurnalperempuan.o $\mathrm{rg} /$ wacana-feminis/fenomenaoperasi-cesar-sebagai-tren. Data diakses pada 5 Juli 2019.

Prawirohardjo, S. 2010. Ilmu Kebidanan. Jakarta: PT Bina Pustaka.

Rusdiana, N., Safitri, M., Resti, A. 2016 Evaluasi penggunaan antibiotika profilaksis pada pasien bedah sesar terencana di Rumah Sakit Ibu dan Anak ' $X$ ' di Tangerang. Social Clinical Pharmacy Indonesia Journal, 1(1):67-75.

Ryan, T.P. 2013. Sample Size Determination and Power, Sample Size Determination and Power. New Jersey: John Wiley \& Sons, Inc.

Shamna, M.S., Kalaichelvan, V.K., Marickar, Y.M.F., Deepu, S. 2014. Cesarean section and prophylactic antibiotics. IOSR Journal of Pharmacy and Biological Sciences, 9(2):51-54.

Sumanti, E.W., Ayu, W.D., Rusli, R. 2016. Pola penggunaan antibiotik profilaksis pada pasien bedah sesar (sectio caesarean) di
Rumah Sakit Islam Samarinda. Prosiding Seminar Nasional Kefarmasian Ke-3, Samarinda 2021 April 2016, Fakultas Farmasi Universitas Mulawarman.

Triyono, T. 2003. Penjelasan teknik sampling dalam penelitian. in Penataran Analisis Data Penelitian bagi Dosen PTS Kopertis XI. Palangkaraya: Kopertis XI.

Vieira, G.O., Fernandes, L.G., de Oliveira, N.F., Silva, L.R., Vieira, T.O. 2015. Factors associated with cesarean delivery in public and private hospitals in a city of northeastern Brazil: a crosssectional study. BMC Pregnancy and Childbirth, 15(1):1-9.

WHO. 2015. Trends in Maternal Mortality: 1990 to 2015. Geneva: WHO.

Wibowo, M.I.N.A., Pratiwi, R.A. Sundhani, E. 2018 Studi prospektif potensi interaksi obat golongan antibiotik pada pasien pediatri di Rumah Sakit Ananda Purwokerto. Pharmacy Jurnal Farmasi Indonesia, 15(2):243256. 